\title{
ARGENTINE STEM WEEVIL: A PEST OF MAIZE
}

\author{
W. M. KAIN AND M. A. BARKER* \\ Research Division, Department of Agriculture, Hamilton
}

Summary

In the summer of 1965-6, the Argentine stem weevil (Hyperodes bonariensis Kuschel) caused severe damage to maize crops in the South Auckland-Waikato area. Symptoms of damage were failure to emerge, wilting, collapse and death at the two- to four-leaf stage, yellow streaking of leaves, stunting, premature tillering, and splitting of the stems. Crops that were badly hit were grown on land newly cultivated out of old ryegrass swards. Evidence from field and laboratory observations suggests that the mode of infection in these instances was a transfer of larvae from decomposing turfs into the emerging maize.

\section{INTRODUCTION}

Hyperodes bonariensis Kusciel (Argentine stem weevil), was first observed in New Zealand at Nelson in 1927 by Miller but was identified by Marshall (1937) as H. griseus Hustache. Kuschel (1955) noted that this was in fact $H$. bonariensis Kuschel.

Morrison (1935 and 1938) established that $H$. bonariensis could complete its life-cycle on wheat, Danthonia pilosa, Dactylis glomerata, Lolium perenne, L. multiflorum, L. hybridum (var.) and barley. Jacques (1940) and Doull (1954) enabled Cynosurus cristatus and Phleum pratense, respectively, to be added to the host list of $H$. bonariensis. Kelsey (1958) reported that Anthoxanthum odoratum, Festuca rubra var. fallax, and oats were also within the host range. $\mathrm{He}$ also recorded that adults fed and laid eggs on young rape but that larvae were not seen to mine it intensively. The writers have observed the newly bred Ariki ryegrass (Lolium perenne $X$ $L$. multiflorum , which is regarded as showing tolerance to $H$. bon ariensis, supporting large populations of larvae in the Whakatane area.

It is apparent that $H$. bonariensis, unlike some weevils, is not monophagous but attacks a wide variety of graminaceous plants, namely, the common cereals and pasture grasses. Adults, however, appear to feed on host plants on which oviposition has not been observed. Kelsey (1958) noted that adults damaged clovers (Trifolium spp.), lucerne and cruciferous plants. With the exception of rape, no eggs or larvae were reported on these dicotyiedons.

During November, 1965, several instances of damage by $H$. bonariensis to maize were recorded in the Waikato, Hauraki Plains and Stratford areas. Since maize had not bcen previously recorded as a host plant, an investigation was carried out.

\section{EXPERIMENTAL}

This investigation was based on field observations and laboratory greenhouse studies.

* Now at Zoology Department, Auckland University. 


\section{Field ObSERvation}

\section{(a) Survey}

This was carried out on sowings that suffered severe weevil damage. Facts gathered included cultural practices, sowing dates, previous use of paddocks, and severity of damage at various stages of growth. The results of this survey are recorded in Table 1.

\section{(b) Symptomolagy}

Plants gathered from study areas were examined and dissected. Symptoms exhibited by infested plants were as follows:

\section{(1) Failure to Emerge, after Seed had Germinated}

In one area, four seedlings were found that had not emerged and in these cases coleoptiles had been mined where the seed split the testa. Unfortunately, observations were too late to gather more conclusive data on this type of damage, except in a laboratory study.

\section{(2) Wilting and Death}

Plants at the 1- to 3-true-leaf stage wilted, giving the plant a purplish-grey tinge, and then collapsed. Dissection revealed extensive mining within the crown of the plant. Entry in most instances was gained $1 / 4$ to $3 / 4$ in. below soil level.

\section{(3) Leaf Streaking}

Plants mined by larvae and which survived were invariably found to exhibit a prominent yellow streaking of the leaves. Streaking occurred along the length of the leaf and could be traced to a lower part of the leaf sheath where the larvae had tunnelled or chewed part of the sheath severing the vascular tissue. This damage manifests itself as a yellow streak immediately above the point of damage.

In some plants at the eight-true-leaf stage as many as four leaves may show streaking, depending on the extent of damage to the crown, but it is more usual on one or two leaves.

Dissections were made of 320 plants collected from Matamata and Rukuhia, varying in size from the 5- to 11-true-leaf stages and all showing yellow streaking symptoms. All these plants had suffered mining damage. However, random sampling on the earlyand late-sown crops of maize revealed that, of the plants with larval entry holes, only 93\% and 53\%, respectively, showed leaf streaking. Mining unaccompanied by leaf streaking may be due to such factors as insufficient time between entry of the larva into the plant and dissection of the plant for symptoms to develop, or larval entry occurring below the crown or in the anchor roots and not, therefore, affecting upward conduction to the leaf.

\section{(4) Splitting, Tillering and Stunting}

Larvae enter and may mine up the inside of the outer sheaths. This type of mining led in some cases to splitting of the sheaths down this fault line as a result of meristematic pressure exerted from the crown of the plant. Plants that survived early crown mining became stunted; in some instances this damage seems to stimulate plants to tiller at an earlier age than uninfected plants. Plants showing these symptoms all have yellow leaf streaking. 


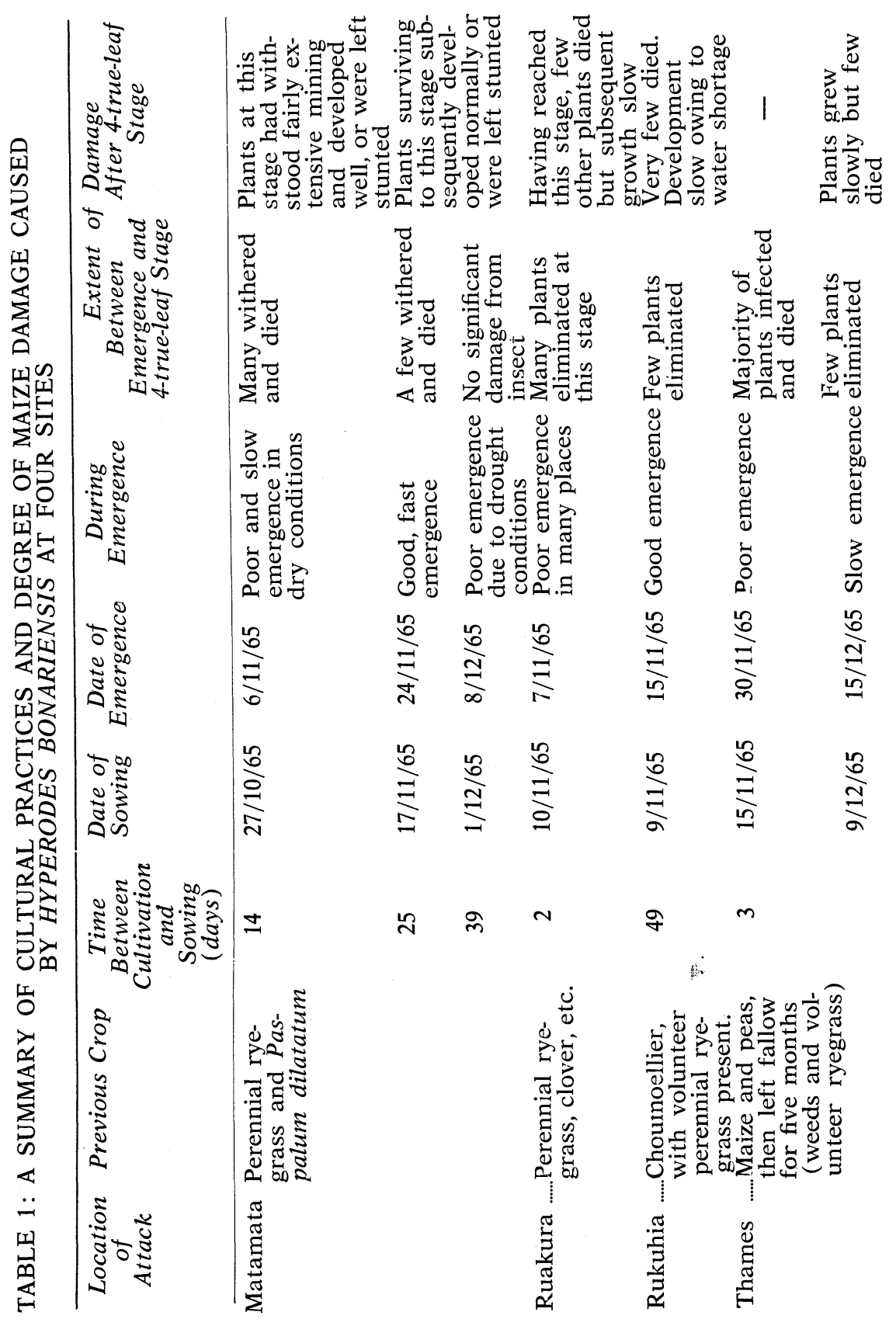




\section{(5) Minings}

Dissection of over 100 plants at the four-leaf stage showed that the mean height of entry was $0.2 \mathrm{in}$. above the crown $(1 / 4$ to $1 / 2 \mathrm{in}$. below the ground) and this point ranged from the very base of the stem to a height of 0.75 in. Mining at this stage was extensive and resulted in stunted plants or death. Brown faeces were evident in the mines. The mean dimensions of the larvae found were $0.022 \mathrm{in}$. by $0.1 \mathrm{in}$. in length.

Damage in plants which developed past the four-leaf stage was much less extensive and was confined to minings in secondary tillers and around the peripheral tissues and in the tender young leaves.

\section{Laboratory Greenhouse ObServations}

To supplement field data, experiments on potted maize were carried out.

Seeds were sown and plants raised in autoclaved soil in pint preserving jars covered with $1 / 32$ in. mesh fibreglass netting. Maize seeds were germinated in petrie dishes on moist filter paper and exposed to larvae. Seeds of Wisconsin Hybrid 575 treated with mercuric chloride were used.

\section{Results}

Six pots were each sown with three maize seeds, which were allowed to develop into two-true-leaf stage, 4 in. high plants. Pieces of perennial ryegrass about $1 / 2$ in. long and containing $H$. bonariensis eggs were placed close to each plant. Three weeks later the plants were uprooted and dissected; 60\% showed minings, and larvae were actually present within some of the plants. No plants were dead, although they did not appear to be healthy. Entry holes were above ground level.

In a second experiment, plants were sown as above and at a similar stage pieces of ryegrass containing larvae were placed in the pots. After two weeks, $50 \%$ of the plants had wilted and collapsed. They were found to be extensively mined. Larvae were found within the plant, while three were pupating in the soil. The symptoms observed were identical with those described from field observations. As in the previous experiment, entry holes were above ground level.

Seeds treated with the fungicide mercuric chloride were sown in three petrie dishes on wet filter paper. Seeds in one dish had the testa removed, while the others were left intact. Larvae were added, in one dish being placed on the seeds, and in the other two, including that containing seeds without testas, three larvae being merely added to the dish. Infection with larvae took place just prior to testa rupture, and seeds were dissected after being left overnight ( 12 hours). Larvae were recovered from seeds in all three dishes. Larvae entered the seed through the ruptured testa and/or burrowed into the developing coleoptile.

Twenty adult weevils swept from pasture in the evening were confined for seven days on 11 pots each containing maize plants and perennial ryegrass at the 2- to 3-leaf stage. No eggs were laid, although feeding damage occurred on all plants. This was repeated later in the season and a small number of eggs were laid on ryegrass but not on maize.

Fifteen adult weevils were also confined for seven days in pots in which maize seeds were germinating. The 1- to 2-true-leaf plants and the old attached seeds were then examined. All the plants 
germinated. Although the seedlings suffered varying degrees of damage from feeding adults it was not severe enough to kill them and no eggs were laid.

\section{DISCUSSION}

Observations in the laboratory show conclusively that: (a) Larvae are capable of moving from one host to another - Pottinger (1961) showed that larvae dissected from ryegrass would remine this host; (b) eggs may hatch on dead and dying material and mine another host; (c) larvae are capable of preventing emergence of corn plants by mining the coleoptile. A large number of adult weevils held on germinating plants did not inflict sufficient damage to kill emerging plants. The experiments suggest that maize is not a preferred host for oviposition as adults caged upon succulent maize plants could not be induced to oviposit though they would on ryegrass. This suggestion is borne out by field studies in which only six singly oviposited eggs were observed; these were on a late-sown crop at Matamata.

From field observations, the following facts emerged:

(1) All areas that were severely damaged had just previously been perennial ryegrass pasture or volunteer ryegrass, except Thames, which was a very narrow elongated trial plot, sown after a fallow directly up against a ryegrass paddock. Damage in this pacldock was along the margins, indicating a movement of larvae into the emerging maize. The time between cultivation and sowing varied from 2 to 14 days. At Matamata, maize was sown at three dates but cultivation of the paddock was simultaneous. Damage observed in the subsequent crops showed that, the longer the period between cultivation and sowing, the less severe was damage.

(2) Investigation of volunteer ryegrass within maize crops shooting from undecomposed turfs revealed a high population of weevil larvae. Crops at Matamata and Ruakura were sown out of ryegrass pasture, too poor to consider renovating. Pastures bordering these paddocks were considered equally poor and were severely infested with $H$. bonariensis. This would indicate that a high population of $H$. bonariensis existed in the paddock prior to cultivation.

Although $H$. bonariensis was observed to infest maize, it may only do so as a survival mechanism in the absence of a preferred host. Out of the hundreds of maize plants that were dissected, only six singly oviposited eggs were found and these on a late-sown crop. On the adjacent ryegrass plants, eggs were oviposited in twos and threes and seldom was one egg laid in an oviposition site. This lack of preference for maize was also observed in the larval stage, as out of the total number of larvae found in maize $66 \%$ were dead. This may be a result of tissue lignification which seems to occur rapidly after the 6-true-leaf stage. On the other hand, mature larvae taken from maize were observed to pupate in soil, suggesting that larvae infesting maize can complete their life-cycle, provided the maize is at the young and succulent stage.

In the majority of plants, entry holes were larger than those resulting from newly hatched larvae. Near-mature larvae entering uninfected maize plants were taken from the field. The majority of plants examined from the field possessed entry holes $1 / 4$ to $1 / 2$ in. below ground level. In the laboratory observations, all plants infected by larvae and eggs placed in potted plants entered above ground level, suggesting that transfer can take place below the surface. 
In all paddocks that were severely attacked, the onset of wilting and death occurred 7 to 14 days after emergence. Plants wilting or dying were dissected, exposing a range of early, middle and mature aged larvae. Larvae at the iatter two stages could not have reached this stage of development on maize in the intervening time. For example, at Thames the first sowing was made on November 15, For example, at Thames the first sowing was made on 29,1965 . Yet by December 9,1965 , the crop had been so extensively damaged as to warrant a second sowing. Pottinger (1961) cites the minimum time for development from the egg into the larva as being 12 days; it seems inconceivable that, even under milder conditions, eggs oviposited on the emerging plants could produce larvae in the 10-day period.

Sampling plants from the field from 2 to 4 weeks after emergence revealed that a large percentage of mines were unoccupied. This may have been because larvae had moved into another plant after preliminary mining or because they had pupated in the soil. The former seems the more likely, as intensive searching in the study areas revealed only one pupa. However, semi-mature larvae were observed entering uninfected and infected maize plants, and larvae varying in maturity were collected from the soil.

A high incidence of infection was observed round the headlands and verges of the paddock. This is thought to be due to the presence of undecomposed turfs supporting $H$. bonariensis populations or to movement of larvae from the ryegrass verges into the maize. It is well known that one tiller of ryegrass usually contains no more than one larva. However, many times this number of eggs are laid on heavily infested ryegrass, and it is therefore probable that the resulting larvae move to other plants.

The evidence strongly suggests that maize plants are infected and killed by $H$. bonariensis larvae and that the mode of infestation is by transfer from ryegrass turfs into emerging or emerged maize. Laboratory and field observations suggest that the larva of $H$. bonariensis is more hardy than other mining larvae and is capable of movement from host to host. Severe damage is caused by larvae evacuating dying ryegrass turfs and mining the crown of newly emerged or emerging maize plants. These larvae may be semimature or have arisen from eggs hatching from dead material. Damage from $H$. bonariensis arising from oviposition on maize is thought by the writers to be of little or no consequence, as, by the time eggs have been laid and hatched on emerged plants, the maize seems unacceptable or tolerant to larvae. Lignification of fibrous tissue by then is well under way and damage at this stage is usually limited to small circling of the leaf sheath and anchor roots.

\section{REFERENCES}

Doull, K. M., 1954: Cant. Agric. Coll. Annu. Rev.: 58.

Jacques, W. A., 1940: N.Z. J. Sci. Tech., 22A: 128.

Kelsey, J M 1958: N.Z. J. agric. Res., 1: 790.

Kuschel, G., 1955: Neuvas sinomimas y anolaciones Soure Curculianidea (1) Revista Chilena de Entomologia, iv: 261. [Lit. cit. Pottinger, 1961].

Marshall, G. A. K., 1937: Trans. Roy. Soc. N.Z., 67: 316.

Morrison, L., 1935: Pests of wheat crops. Cant. Agric. Coll. Bull., 71: 1-2.

1938: Survey of Insect Pests of Wheat Crops in Canterbury and North Otago during the Summer of 1937-1938.

Pottinger, R. P., 1961: Argentine stem weevil, Hyperodes bonariensis, an insect pest of pastures. Cant. Chamb. Comm. Agric. Bull. 380 . 